\title{
A Review on a Bio-Synthetic Pathway: Melanogenesis
}

\author{
Triparna Pahari ${ }^{1}$, Kasturi Chattopadhyay ${ }^{2}$, Susmita Mukherjee $^{3 *}$ and Susmita Jana ${ }^{4}$ \\ ${ }^{1}$ Department of Fish Genetics and Breeding, ${ }^{2}$ Department of Post-Harvest Technology \\ ICAR-Central Institute of Fisheries Education (CIFE), Mumbai-400 061, India \\ ${ }^{3}$ Department of Fish Processing Technology, ${ }^{4}$ Department of Fisheries Resource Management \\ West Bengal University of Animal and Fisheries Science, Kolkata- 700 094, India
}

*Corresponding author

\section{Keywords}

Melanogenesis, Eumelanin,

Pheomelanin,

Polydopamine,

Biological

application

\section{Article Info}

Accepted:

18 April 2020

Available Online:

10 May 2020

\section{A B S T R A C T}

Melanogenesis is a complex process that involves many genes which leads to production and distribution of the melanin pigment. Melanin is a dark biological pigment derived by the oxidation and subsequent polymerization of phenolic compounds. There are two types of melanin viz., eumelanin (black-brown color) and pheomelanin (yellow-red color). Melanin is found in different parts of the body of the animal like skin, brain, eye, ear and perform different functions apart from pigmentation. The main biosynthetic pathway of melanogenesis in all animals is Raper-Mason pathway. Melanogenesis pathway is regulated by different pathways which involve many genes like MC1R, AC, $\beta$-catenin, RAS, BRAF, MAPK, MITF etc. Melanin has very unique properties like redox capacity, metal chelating properties or free radical scavenging properties etc. Because of these properties Melanin and melanin like materials (PDA-polydopamine) have different applications in the field of dermatology, cosmetics, biomedicine as well as anti-pollution product technologies and many more. This review presents a general overview of melanin and melanogenesis in different types of organisms and applications of melanin in different biological fields.

\section{Introduction}

Melanogenesis by definition is the production of the melanin pigments; which is produced by cells called melanocytes (D'Mello et al., 2016).The epidermal units of the skin are responsible for melanin production and distribution by the melanogenesis process. There are many proteins, hormones and enzymes are involved in melanogenesis process which may be regulating the melanin production directly or indirectly (Videira et al., 2013).

Over the past decade, melanin and melanogenesis have been increasingly valued not only for the pigment related study but also studied as a source of novel research opportunities in the fields of dermo cosmetics, biomedicine, nanotechnology, and other 
biotechnological fields. The purpose of this study is to give a brief overview of the melanin, the pathway and genes involved in melanogenesis, the biological functions, synthesis procedure, application and also the disorders associated with this to attract significant research interest from researcher in the fields of biological, chemistry and medicine.

\section{Melanin- definition}

The name "melanin" comes from the ancient Greek word "melanos", meaning "dark". The term was first used by the Swedish chemist Berzelius in 1840 to call a dark pigment extracted from eye membranes.

Melanin is considered as a heterogeneous polymer produced from the oxidation of phenol and subsequent polymerization of intermediate phenols and their resulting quinones (Nicholas et al., 1964). Melanin is of two types-1. Eumelanin (Black or Brown), 2. Pheomelanin (Yellowish to Reddishbrown) formed by the conjugation of cysteine or glutathione (Slominski et al., 2004).

Eumelanin is dominant in the individuals with dark skin and hair and is more effective in photo protection. Pheomelanin is predominantly found in individuals with red hair and skin, in whom skin tumour is more common as it is less efficient in photo protection.

\section{Biological functions of melanin in different animals}

Melanin, the well-known biopolymers are distributed widely in animals, microorganisms, plants, and play significant physiological roles (Solano, 2014). Some of the important functions are described in Table 1 .

\section{Genes involved in melanogenesis}

Melanogenesis is a complex process which is regulated by many genes (Videira et al., 2013). In order to understand the pathogenicity of pigmentation disorders and subsequent development of potential therapeutic options, there is an urge for correct identification and comprehension of the genes regulating the mechanism of melanogenesis. Table 2 represents the list of different genes involved in melanogenesis and those which are responsible for melanin synthesis and regulation.

\section{Biochemical pathways for melanogenesis}

According to variations in the structure and occurrence of melanin, its biogenesis is not a single and universal process. The study on various organisms led several biosynthetic pathways in melanin synthesis (Solano, 2014). The general features in all the pathways involve an initial phase with the enzymatic-catalyzed oxidation of phenolic precursors to quinones followed by a final phase consisting of the mostly unregulated polymerization of quinones. The different bio synthetic pathways of different organisms are mentioned in Table 3. The most universal and well-known pathway of animal is called the Raper-Mason pathway which is described below.

\section{Raper-mason pathway of melanogenesis}

The initiation process of melanogenesis begins by virtue of the key enzyme, Tyrosinase (TYR)

which oxidizes L-tyrosine to DopaQuinone (DQ)

The resulting DopaQuinone (DQ) will serve as a substrate for the synthesis of eumelanin and pheomelanin (Fig. 1). 


\section{Eumelanin synthesis}

The formation of DQ is a rate-limiting step in the melanin synthesis

After DQ formation, it undergoes intramolecular cyclization to produce indoline, leukodopachrome (cyclodopa)

The redox exchange between leukodopachrome and DQ give rise to dopachrome and L-3,4dihydroxyphenylalanine (L-DOPA)

L-DOPA is also a substrate for TYR and oxidized to DQ again by the enzyme.

Dopachrome gradually decomposes to give dihydroxyindole (DHI) and dihydroxyindole-2-carboxylicacid (DHICA). The later process is catalyzed by TYRP-2 (Tyrosinase Related Protein-2) or Dopachrome tautomerase (DCT).

Ultimately, these dihydroxyindoles (DHI and DHICA) are oxidized to eumelanin.

TYRP-1 (Tyrosinase Related Protein-1) is catalyse the oxidation of DHICA to Indole-5,6-Quinone Carboxylic Acid (IQCA), which is a structural unit of eumelanin (Fig. 2).

\section{Pheomelanin synthesis}

DQ is converted to 5-S-cysteinyldopa or glutothionyldopa in the presence of cysteine or glutathione.

Subsequent oxidation gives benzothiazine intermediates and finally produces pheomelanin.

\section{Regulation of melanogenesis}

Regulation of melanogenesis at the subcellular level where the gene expression encoded by the melanogenesis-related enzymes including TYRP-1, TYRP-2 and TYR is regulated by intracellular pathways.
These signal pathways are initiated by a variety of hormones which gives complex signals that responds to UV exposure or other environmental stimulations.

There are three most commonly known signal pathways involved in the regulation of melanogenesis (Pillaiyaret al., 2015)-

cAMP (Cyclic Mono Phosphate)depended signalling pathway

Wnt signalling pathway

ERK (Extracellular SignalRegulated Kinase) signalling pathway

All three signal pathways involve Micropthalmia-associated transcription factor (MITF)(Vance and Goding, 2004).

\section{Micropthalmia associated transcription factor (MITF)}

MITF is the master regulator of melanogenesis (Pogenberget al., 2012).

MITF is a basic helix-loop-helix leucine zipper transcription factor protein that encodes 520 amino acids, this protein is encoded by MITF gene consisting of 1563 nucleotides.

It has basic domain which is used for DNA binding (Figure- 3 ).

HLH and Zip domains that are used for homo- and/or heterodimer formation.

It binds to the $\mathrm{M}$ box of a promoter region (3'-CANNTG-5') of the pigmentary gene tyrosinase (TYR), TYRP-1 (Tyrosinase Related Protein-1) and TYRP-2 (Tyrosinase Related Protein2) and regulates their expression

MITF is also regulates the expression of Bcl2 (B-cell lymphoma 2) which is involved in the survival, proliferation, and differentiation of melanocytes cells 
Genes involved and diseases associated with abnormal melanogenesis

There are many genes involved in the melanogenesis pathway. Mutation of these genes leads to different melanogenic disorders which are tabulated in Table 4.

\section{Melanin synthesis: natural and synthetic}

\section{Extraction and purification of natural melanin}

There are many different methods which are involved for melanin extraction form different natural sources. The methods are like chemical extraction and purification, matrixassisted laser desorption, ionization massspectrometry or pyrolysis gas chromatography etc. The different sources of natural melanin synthesis and the extraction procedures are tabulated in table 5 .

\section{Synthetic melanins by oxidation of L-Dopa}

There are also melanins formed by chemical oxidation from some diphenolic precursors of melanogenesis pathway, like L-3,4dihydroxyphenylalanine (L-DOPA), which is commercially available. The produced melanin known as dopa-melanin and dopamine-melanin, which are easily formed by chemical oxidation of those precursors by generally using atmospheric oxygen or hydrogen peroxide in basic media.

Autoxidation of L-Dopa was obtained by dissolving L-Dopa up to saturation in salt free aqueous solution (for example- borate buffer) at different $\mathrm{pH}$ and stirred in air.

After polymerization of sample, it is finally prepared under different conditions of ionic strength (Bridelli, 1998). Enzymatic oxidation of L-Dopa is synthesized by the tyrosinase (Example- Mushroom Tyrosinase), which is the main enzyme involved in melanogenesis.
The aqueous solution is buffered at neutral $\mathrm{pH}$ and stirred in air for some days to get polymerized synthetic melanin (Bridelli, 1998).

Samples obtained both by autoxidation and by enzymatic polymerization appeared as blackbrown solutions which contain mixtures of granules of different average sizes, depending on the $\mathrm{pH}$ in the buffer solution. After polymerization and dilution, the sample is then analysed for the polymerization kinetics. The synthetic melanin is used as model melanin for biophysical studies and other applications of eumelanin.

\section{Applications of melanin}

Over the past decades, applications of melanin and melanogenesis have been increasingly adapted apart from the pigment cell community. They are used as a source of novel research opportunities in the fields of biomedicine, dermo-cosmetics, nanotechnology, materials science etc. The different applications of melanin were previously reviewed by many researchers (d'Ischiaet al., 2015; Solano, 2017; Huang et al., 2018; Qi et al., 2019). In this study some of the applications are described below.

\section{Dermocosmotic applications}

Dermo-cosmetic applications of melanin and melanogenesis include mainly the modulation of the melanogenesis pathway to control skin color like hyperpigmentation. Hyperpigmentation occurs in response to UVinduced DNA damage, inflammation, or other skin injuries etc.

Modulation of melanogenesis to alter the colour and its pattern is passion which has lot of demand and application in human medicine and cosmetics. Literature review suggested that a number of studies has been carried related to the identification of melanogenesis 
modulators, both natural and synthetic and have been used in cosmetics products as hypopigmentation agents (Chang, 2012; Pillaiyar et al., 2015).

\section{Melanin precursor as hair dye}

Colour fading, hair damage or complication in handling, these are some common problems occurred by using of conventional or traditional oxidative hair dyes. As an alternative the natural melanin precursor, likeDHI, DHICA can be used as hair dye. These precursors can be converted into the natural melanin by air oxidation and can be easily penetrate into the hair (d'Ischia et al., 2015).

Although using of this precursor is commercially appealing, but it is methodologically challenging because of the difficulty to obtain a natural hue in the final dye, the relatively low affinity for hair and also penetration is sometimes low.

A valuable biotechnological approach to cover gray hair with melanin precursors by enzymatic oxidation has been developed using a fungus, Aspergillus oryzae (Nakamura et al., 2012). Recent research showed that purified DOPA (one of the precursor product of melanogenesis) is used for the production of DHI and tyrosinase enzyme of Aspergillus oryzae is used as oxidative enzyme to produce melanin from DHI. The formulation leads to lower levels of hair damage than with traditional oxidative hair dyes and the skin staining level is lower than with direct dye systems (Koike and Ebato, 2013).

\section{Melanin in sunscreen}

Oxidation and polymerization of pure dopamine (DA) (precursor product in melanogenesis) gives place to a eumelaninlike material known as polydopamine (PDA) with extraordinary adhesion and coating properties (Lee et al., 2007). Melanin and PDA possess excellent UV/radiation shielding properties, which can protect the skin and body from UV/ radiation damage. They scavenge all kinds of free-radicals that are produced by UV/radiation, thus they are widely applied in UV/radiation protection. Wang et al., 2018 prepared PDA sunscreen (Figure-4) with superior UV shielding properties and improved photo protective capacities. The resulting PDA sunscreens were bio adhesive, water resistant and nonskin penetrative, safe and efficient for human skin protection.

\section{Biomedical applications of melanin}

Inspired by the fascinating characteristics of Polydopamine Melanin (PDAM) many PDAM-based nanomaterial have been strategically designed and synthesized for wide applications in biomedical fields. Some of these applications are described below.

\section{Melanin in antioxidant therapy}

PDAM nanoparticles have been frequently proposed as powerful antioxidants, to protect against damage by free radicals, ROS (Reactive Oxygen Species) and RONS (reactive oxygen and nitrogen species). The nanoparticles display good stability in water and stronger free radical scavenging activity, to slow down the oxidation rate. PDAM has been proposed for treatment of severe diseases related to oxidative stress, such as neurologic disorders and inflammatory diseases (Liu et al., 2017).

\section{Melanin in photothermal therapy}

Photo-thermal therapy (PTT) is an effective therapeutic treatment that has nowadays used to treat the solid cancer as it has deep tissue penetration and it shows minimal effects on the surrounding healthy tissues. This method 
relies on activation of photosensitizing agents which absorb energy and converts into heat by an electromagnetic radiation like microwave, radio frequencies, visible light etc. Due to a high absorption capacity in the infrared region, high conversion ability of that energy to heat and also significant stability to irradiation, PDAM is used widely in PTT to cure cancer (Liu et al., 2013). Another importance of using PDAM nanoparticles is, it is able to kill tumour cells in animal models with short irradiation laser times (Liu et al., 2013).

Table.1 The general roles/functions of melanin in different organisms

\begin{tabular}{|c|c|}
\hline $\begin{array}{l}\text { Organism/org } \\
\text { an }\end{array}$ & Role/function \\
\hline $\begin{array}{l}\text { Cutaneous } \\
\text { Melanin }\end{array}$ & $\begin{array}{l}\text { Sunscreen } \\
\text { Photo-protector } \\
\text { Colour determination }\end{array}$ \\
\hline Ear Melanin & $\begin{array}{l}\text { Appropriate hearing (Gottesberge, 1988) } \\
\text { Biological reservoir of divalent ion } \\
\text { Calcium homeostasis }\end{array}$ \\
\hline $\begin{array}{l}\text { Neuro } \\
\text { Melanin }\end{array}$ & $\begin{array}{l}\text { Toxic element protection } \\
\text { Chelate metal ions (Fe) produced in brain (Sealy, 1984) }\end{array}$ \\
\hline Eye Melanin & $\begin{array}{l}\text { Greater visual activity } \\
\text { Protect retina from Sunlight and Photo- oxidation (Hosseini et al., } \\
\text { 2010) }\end{array}$ \\
\hline $\begin{array}{l}\text { Bird feather } \\
\text { melanin }\end{array}$ & $\begin{array}{l}\text { Photo protection } \\
\text { Abrasion protection } \\
\text { Increase long life of feather (Bonser, 1995) } \\
\text { Help in mate choice }\end{array}$ \\
\hline $\begin{array}{l}\text { Amphibian \& } \\
\text { Fish melanin }\end{array}$ & $\begin{array}{l}\text { Thermoregulation } \\
\text { Camouflage, mate choice, species recognition } \\
\text { Protect from predators }\end{array}$ \\
\hline $\begin{array}{l}\text { Insects } \\
\text { Melanin }\end{array}$ & $\begin{array}{l}\text { Strengthen exocuticle } \\
\text { Defend against microbial infection (Sugumaran,1998) } \\
\text { Shell hardening as the egg matures Ex-helminthes }\end{array}$ \\
\hline $\begin{array}{l}\text { Microorganism } \\
\text { melanin }\end{array}$ & $\begin{array}{l}\text { Protector of very stressful conditions. Ex-Chernobyl } \\
\text { Helps in endospore formation. Ex-Bacillus } \\
\text { Protects from chemical compounds Ex- Bacillus } \\
\text { thuringiensis(Aghajanyan et al., 2005) }\end{array}$ \\
\hline
\end{tabular}


Table.2 List of genes responsible for melanogenesis

\begin{tabular}{|c|c|c|}
\hline Gene & Protein & Function \\
\hline MITF & $\begin{array}{l}\text { Micropthalmia Associated } \\
\text { Transcription Factor }\end{array}$ & $\begin{array}{l}\text { Transcription factor which regulates } \\
\text { function of pigmentary enzymes and } \\
\text { survival of melanocytes }\end{array}$ \\
\hline PAX3 & Paired box gene 3 & $\begin{array}{l}\text { Proliferation, differentiation, survival of } \\
\text { melanocyte }\end{array}$ \\
\hline MC1R & Melanocortin1 receptor & $\begin{array}{l}\text { Receptor of } \alpha \text {-MSH hormone, upregulates } \\
\text { melanogenesis }\end{array}$ \\
\hline $\mathbf{A C}$ & Adenylate Cyclase & Increase cAMP level in melanocyte \\
\hline PKA & Protein Kinase A & $\begin{array}{l}\text { Phosphorylates transcription factors } \\
\text { which activates MITF }\end{array}$ \\
\hline $\begin{array}{c}\boldsymbol{\beta}- \\
\text { Catenin }\end{array}$ & Beta catenin & Upregulates transcription of MITF \\
\hline C-kit & Tyrosine kinase receptor & $\begin{array}{l}\text { Melanocyte physiology, influencing } \\
\text { melanogenesis, proliferation, migration, } \\
\text { and survival of the pigment-producing } \\
\text { cells. }\end{array}$ \\
\hline RAS & Ras GTPase protein & $\begin{array}{l}\text { Melanocyte cell growth, differentiation } \\
\text { and survival by activating RAF protein }\end{array}$ \\
\hline RAF & RAF kinase protein & $\begin{array}{l}\text { Melanocyte cell growth, differentiation } \\
\text { and survival by activating MEK protein }\end{array}$ \\
\hline MEK & $\begin{array}{c}\text { Mitogen-activated protein kinase } \\
\text { kinase }\end{array}$ & Activating ERK protein \\
\hline ERK & Extracellular signal-Regulated Kinase & $\begin{array}{l}\text { Negatively regulates activity of MITF } \\
\text { protein by phosphorylate and ubiquitation }\end{array}$ \\
\hline TYR & Tyrosinase & Initiates melanin biosynthesis process \\
\hline TYRP1 & Tyrosinase Related Protein 1 & $\begin{array}{l}\text { DHICA-oxidase function in } \\
\text { melanogenesis and regulates activity of } \\
\text { TYR. }\end{array}$ \\
\hline TYRP2 & Tyrosinase Related Protein 2 & $\begin{array}{l}\text { Produce DHICA from Dopachrome which } \\
\text { is a precursor product of melanin }\end{array}$ \\
\hline
\end{tabular}

Table.3 Biochemical pathway of melanin synthesis in different organisms

\begin{tabular}{|c|c|c|c|c|}
\hline Organism & Pathway & Precursor & $\begin{array}{c}\text { Main } \\
\text { enzyme }\end{array}$ & End product \\
\hline Animal & $\begin{array}{c}\text { Raper-Mason } \\
\text { pathway of } \\
\text { melanogenesis }\end{array}$ & L-tyrosine & Tyrosinase & $\begin{array}{c}\text { Eumelanin } \\
\text { Pheomelanin }\end{array}$ \\
\hline Plant & $\begin{array}{c}\text { Catechol melanin } \\
\text { synthesis pathway }\end{array}$ & $\begin{array}{c}\text { Catechols, } \\
\text { Caffeic acid }\end{array}$ & $\begin{array}{c}\text { Catechol } \\
\text { Oxidase }\end{array}$ & $\begin{array}{c}\text { Catecol- } \\
\text { Melanin }\end{array}$ \\
\hline Fungal & $\begin{array}{c}\text { Pentaketide } \\
\text { pathway }\end{array}$ & $\begin{array}{c}1,8 \text { DiHydroxyNaphathale } \\
\text { ne(1,8-DHN) }\end{array}$ & Laccase & $\begin{array}{c}\text { DHN- } \\
\text { melanins }\end{array}$ \\
\hline
\end{tabular}


Table.4 Genes and Diseases associated with hypopigmentation (Spritz and Hearing, 2013)

\begin{tabular}{|c|c|c|c|}
\hline Gene & Disease & Inheritance & Protein \\
\hline KIT & Piebaldism & Dominant & Receptor tyrosine kinase \\
\hline MITF & $\begin{array}{l}\text { Waardenburg syndrome(type } \\
\text { IIA) }\end{array}$ & Dominant & $\begin{array}{l}\text { Micropthalmia (mi) associated } \\
\text { Transcription Factor }\end{array}$ \\
\hline HPS1 & $\begin{array}{c}\text { Hermansky-Pudlak syndrome } \\
1\end{array}$ & Recessive & $\begin{array}{l}\text { BLOC-3 component (Biogenic } \\
\text { Lysosome related organelles } \\
\text { complex-3) }\end{array}$ \\
\hline FOXD3 & Generalized vitiligo & Dominant & $\begin{array}{l}\text { Neural crest melanoblast } \\
\text { differentiation regulator }\end{array}$ \\
\hline TYR & $\begin{array}{l}\text { Oculocutaneous albinism type } \\
\text { I }\end{array}$ & Recessive & Tyrosinase \\
\hline OCA2 & $\begin{array}{l}\text { Oculocutaneous albinism type } \\
\text { II }\end{array}$ & Recessive & OCA2 melanosome protein \\
\hline TYRP1 & $\begin{array}{l}\text { Oculocutaneous albinism type } \\
\text { III }\end{array}$ & Recessive & $\begin{array}{c}\text { DHICA oxidase/Tyrosinase Related } \\
\text { Protein } 1\end{array}$ \\
\hline SLC45A2 & $\begin{array}{l}\text { Oculocutaneous albinism type } \\
\text { IV }\end{array}$ & Recessive & $\begin{array}{l}\text { MATP(Membrane-associated } \\
\text { transporter protein) }\end{array}$ \\
\hline
\end{tabular}

Table.5 Different types of extraction and purification procedures applied to various melanin types (Pralea et al., 2019)

\begin{tabular}{|c|c|c|}
\hline \multicolumn{2}{|c|}{ Melanin source } & General method of Extraction and Purification \\
\hline $\begin{array}{l}\text { Fungal } \\
\text { melanin }\end{array}$ & $\begin{array}{l}\text { Boletus griseus } \\
\text { (Liu et al., 2018) } \\
\text { Auricularia } \\
\text { auricular } \\
\text { (Sun et al., 2016) }\end{array}$ & $\begin{array}{l}\text { Incubation with basic medium }(\mathrm{Ex}-\mathrm{NaOH}) \\
\text { Centrifugation followed by } \mathrm{pH} \text { adjustment } \\
\text { Again centrifugation and precipitate collection and washing } \\
\text { in distilled water } \\
\text { Vacuum freeze-drying of the precipitate hydrolyzation ( Ex- } \\
\text { HCL) } \\
\text { Filtration and washing } \\
\text { Repeated solubilisation in basic medium of the precipitate } \\
\text { followed by pH adjustment } \\
\text { Successive washing and vacuum freeze-drying of the } \\
\text { precipitate }\end{array}$ \\
\hline (Wang & $\begin{array}{l}\text { Sepia ink } \\
\text { and Rhim, 2019) }\end{array}$ & $\begin{array}{l}\text { Dilution of sepia ink paste with distilled water using } \\
\text { homogenizer } \\
\text { Centrifugation followed by washing of the suspension in acid } \\
\text { medium } \\
\text { Drying at proper temperature to obtain dried melanin } \\
\text { particles }\end{array}$ \\
\hline & $\begin{array}{l}\text { uman hair } \\
\text { l et al., 2003) }\end{array}$ & $\begin{array}{l}\text { Repeated hair washing using proper chemical (Example- } \\
\text { acetone, dichloromethane, ether and water) } \\
\text { Suspension of hair in proper buffer solution (Ex- phosphate }\end{array}$ \\
\hline
\end{tabular}




\begin{tabular}{|l|l|}
\hline & buffer) \\
& repeated overnight incubation by using protein degradation \\
enzyme like proteinase K and or papain & centrifugation followed by washing and re-suspension in \\
buffer solution & Triton X-100 treatment was done for protein extraction and \\
then ultracentrifugation and washing with water & At last overnight treatment with protein degradation \\
& enzymes like proteinase K \\
& Successive washing with water and drying to produce \\
& Melanin \\
\hline Bacterial melanin & Centrifugation of bacterial culture followed by acidification \\
& (Example- By using HCL) of the supernatant, produced from \\
& centrifugation \\
& Storage in the dark for some days, usually 7 days \\
Then boiling is done followed by cooling and centrifugation \\
\\
Pellet wash with acid medium and distilled water \\
Then storage at room temperature usually for 1 day \\
After storage residue wash with ethanol followed by air dry \\
\hline
\end{tabular}



Figure.1 Raper-mason pathway of melanogenesis 


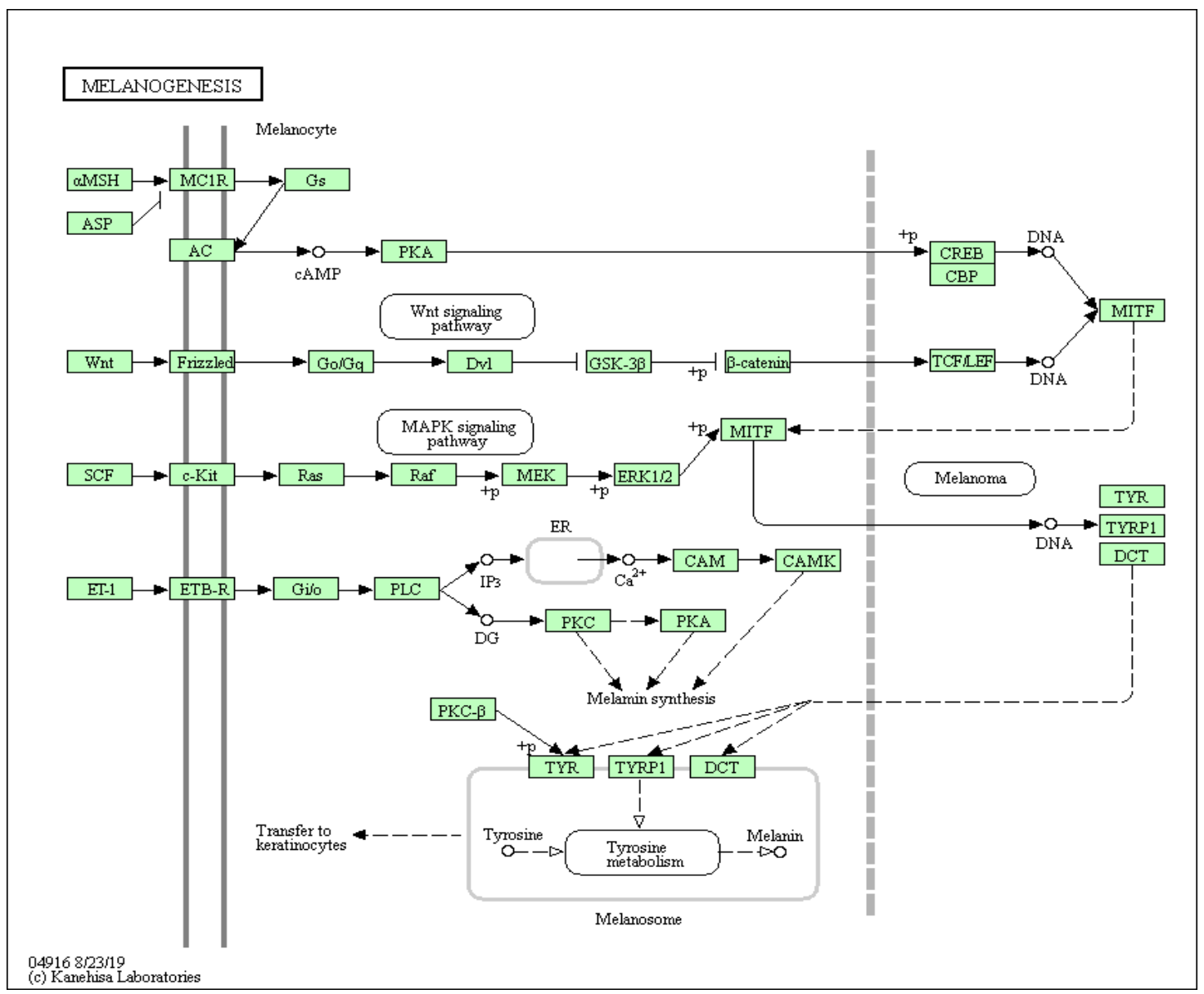

Figure.2 Overall pathway of melanogenesis (melanogenesis pathway map of Kyoto Encyclopedia of Genes and Genomes)

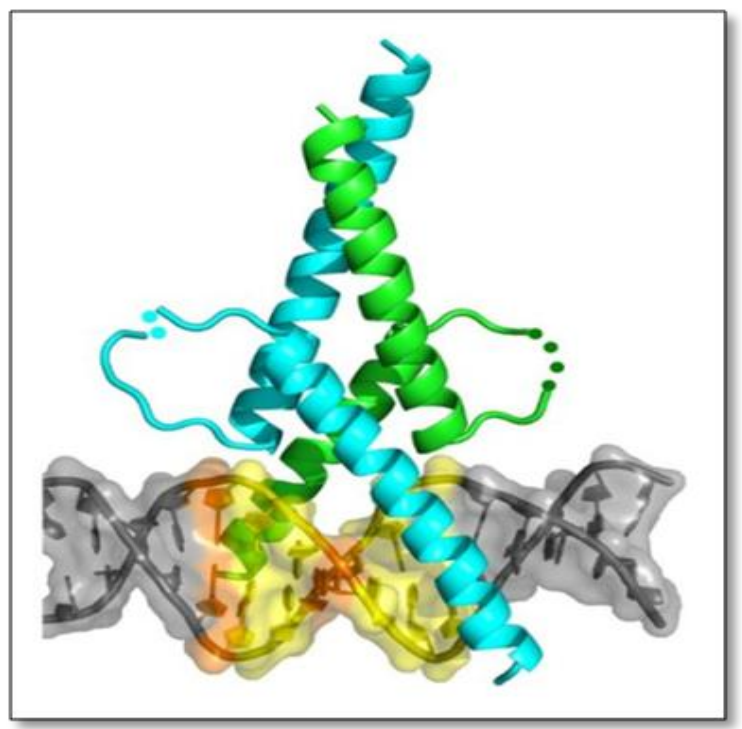

Figure.3 MITF protein dimer binds with DNA (Pogenberg et al., 2012) 


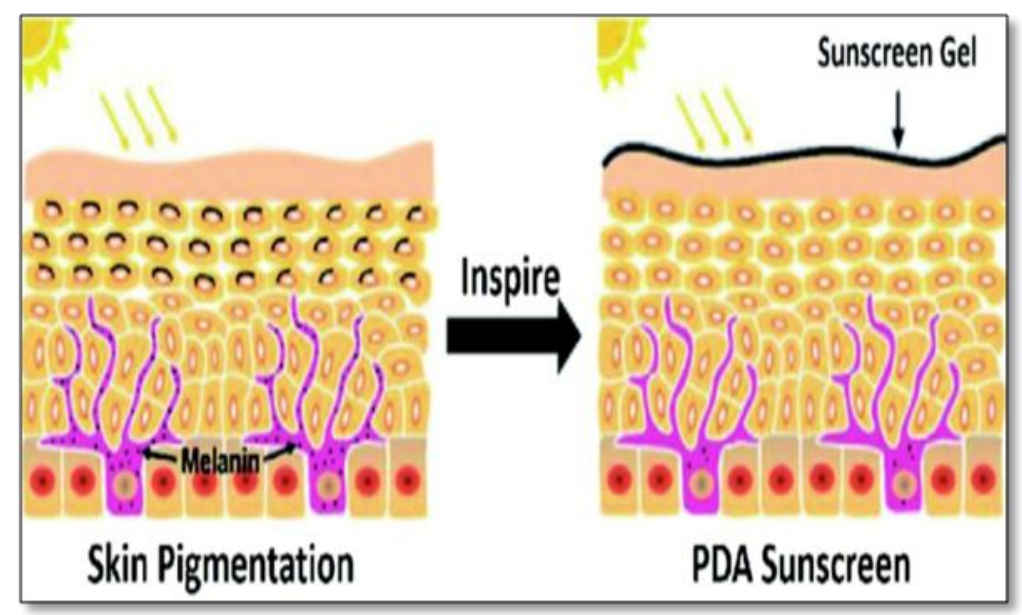

Figure.4 Schematic design of the concept of use of PDA sunscreen gels (Qi et al., 2019)

\section{Melanin nanoparticles as biomedicine}

PDAM is an easy coating of nanoparticles, have a good ability to be conjugated with other materials, biocompatible in nature and can deliver properly nanoparticle-charged active agents to reach its specific targets. These nanoparticles are tailored to be carriers of specific anticancer drugs that should be first preloaded, and later released in the target tissues in response to appropriate stimuli. Previously PDAM nanoparticles have been loaded with anticancer drugs, such as doxorubicin and 7-ethyl-10hydroxycamptothecin (Wang et al., 2016), or sorafenib (Zhang., 2015) to treat with cancer. Melanin-shielded nanoparticles prepared by enzymatic polymerization on silica have been reported to provide excellent protection from radiotoxicity to bone marrow during radioimmunotherapy as well as in some other therapy like external beam radiation therapy, permitting the administration to tumours of significantly higher doses (Schweitzer et al., 2010).

\section{Melanin in tissue engineering}

The intrinsic electroactivity, biocompatibility, outstanding adhesive property, as well as high antioxidant activities of melanin and PDA make them ideal biomaterials for skeletal muscle tissue engineering. Designed biomaterial scaffolds employed by skeletal muscle tissue engineering (SMTE) promote myogenic differentiation of myoblasts to functional myotubes.

Manchineella et al., 2016 developed silk fibroin / melanin composite films and scaffolds for the promotion of Myogenesis. The incorporated melanin could modulate the thermal stability and electrical conductivity of these scaffolds, and impart the antioxidant properties to the scaffolds.

Due to their good adhesive properties, melanin coatings are useful for implantable biomaterials which can prevent material displacement from the site of implant. Melanin coated scaffold has the ability of both cancer therapy and bone regeneration (Ma et al., 2016)

\section{Synthetic melanin as water purifier}

A simple oxidation polymerization of 3,4dihydroxy-phenylalanin (DOPA) along with $\mathrm{KMnO}_{4}$, led to lucrative synthesis of spherical-shaped melanin nanoparticles 
having good water-dispersibility. Kim et al., (2012) investigated their binding ability with many heavy metal ions in aqueous solution and found the binding capacity to be maximum with copper, lead and cadmium. Thus, melanin nanoparticles can turn out to be excellent remediator of contaminated water due to its highly efficient and expeditious binding capacity to metal ions.

In conclusion, this study showed that melanin is a powerful bio-molecule that goes far beyond being just a cutaneous photoprotective pigment in skin. Melanogenesis, the process of melanin synthesis, is regulated by many genes. The importance of each of these genes and their mechanisms are evident in clinical genetic defects and the identification of these defects has contributed to a better understanding of the melanocyte biology and melanogenesis regulation. Recent advances on melanin applications suggest that both natural and synthetic like-molecules, is indeed excellent materials for bioelectronics and biomedical purposes, due to their unique properties like light absorbance, radical scavengers, ion chelating agent, polymers with strong binding capacity etc.

Despite all of these recent advancement and application, however, several challenges must be introduced before melanin-based technology becomes a developed field. There is a need to expand the efforts toward a deeper understanding of the conductivity properties of melanin to optimize their response for applications in organic electronics, bioelectronics and other more specific applications. These goals can be easily achieved through cooperation between researchers involved in academic, industrial, and clinical settings, which should encourage an increasing number of companies to invest on melanin research for innovative and sustainable solutions for human health and technology.

\section{References}

Aghajanyan, A.E., Hambardzumyan, A.A., Hovsepyan, A.S., Asaturian, R.A., Vardanyan, A.A. and Saghiyan, A.A., 2005. Isolation, purification and physicochemical characterization of water- soluble Bacillus thuringiensis melanin. Pigment cell research, 18(2), pp.130-135.

Bonser, R.H., 1995. Melanin and the abrasion resistance of feathers. The Condor, 97, pp.590-591

Bridelli, M.G., 1998. Self-assembly of melanin studied by laser light scattering. Biophysical chemistry, 73(3), pp.227-239.

Chang, T.S., 2012. Natural melanogenesis inhibitors acting through the downregulation of tyrosinase activity. Materials, 5(9), pp.1661-1685.

D’Mello, S.A., Finlay, G.J., Baguley, B.C. and Askarian-Amiri, M.E., 2016. Signaling pathways in melanogenesis. International journal of molecular sciences, 17(7), p.1144.

d'Ischia, M., Wakamatsu, K., Cicoira, F., Di Mauro, E., Garcia- Borron, J.C., Commo, S., Galván, I., Ghanem, G., Kenzo, K., Meredith, P. and Pezzella, A., 2015. Melanins and melanogenesis: from pigment cells to human health and technological applications. Pigment cell \& melanoma research, 28(5), pp.520-544.

Elsaesser, A. and Howard, C.V., 2012. Toxicology of nanoparticles. Advanced drug delivery reviews, 64(2), pp.129-137.

Gottesberg E, A.M.Z., 1988. Physiology and pathophysiology of inner ear melanin. Pigment cell research, 1(4), pp.238-249.

Hosseini, M. S, B. N. Araabi, andH. SoltanianZadeh, "Pigment melanin: pattern for iris recognition," IEEE Transactions on Instrumentation and Measurement, 59, pp. 792-804, 2010.

Huang, L., Liu, M., Huang, H., Wen, Y., Zhang, X. and Wei, Y., 2018. Recent advances and progress on melanin-like materials and their biomedical applications. Biomacromolecules, 19(6), pp.1858-1868.

KEGG Pathway database. Available online: http://www.genome.jp/kegg/pathway.html ( 
accessed on 7 August 2012).

Kim, D.J., Ju, K.Y. and Lee, J.K., 2012. The synthetic melanin nanoparticles having an excellent binding capacity of heavy metal ions. Bulletin of the Korean Chemical Society, 33(11), pp.3788-3792.

Koike, K., and Ebato, A. (2013). One-pack hair dye compositions containing indole compounds. JpnTokkyoKoho 2013, JP5363703B220131211.

Lee, H., Dellatore, S.M., Miller, W.M. and Messersmith, P.B., 2007. Mussel-inspired surface chemistry for multifunctional coatings. science, 318(5849), pp.426-430.

Liu, Q., Xiao, J., Liu, B., Zhuang, Y. and Sun, L., 2018. Study on the Preparation and Chemical Structure Characterization of Melanin from Boletus griseus. International journal of molecular sciences, 19(12), p.3736.

Liu, Y., Ai, K., Liu, J., Deng, M., He, Y. and Lu, L., 2013. Dopamine- melanin colloidal nanospheres: an efficient near- infrared photothermal therapeutic agent for in vivo cancer therapy. Advanced materials, 25(9), pp.1353-1359.

Liu, Y., Kempf, V.R., Brian Nofsinger, J., Weinert, E.E., Rudnicki, M., Wakamatsu, K., Ito, S. and Simon, J.D., 2003. Comparison of the structural and physical properties of human hair eumelanin following enzymatic or acid/base extraction. Pigment cell research, 16(4), pp.355-365.

Liu, Y.; Ai, K.; Ji, X.; Askhatova, D.; Du, R.; Lu, L.; Shi, J. Comprehensive insights into the multi-antioxidative mechanisms of melanin nanoparticles and their application to protect brain from injury in ischemic stroke. J. Am. Chem. Soc. 2017, 139, 856-862

Ma, H., Luo, J., Sun, Z., Xia, L., Shi, M., Liu, M., Chang, J. and $\mathrm{Wu}, \mathrm{C}$., 2016. 3D printing of biomaterials with mussel-inspired nanostructures for tumor therapy and tissue regeneration. Biomaterials, 111, pp.138148.

Magarelli, M., Passamonti, P. and Renieri, C., 2010. Purification, characterization and analysis of sepia melanin from commercial sepia ink (Sepia Officinalis). Revista CES MedicinaVeterinaria y Zootecnia, 5(2), pp.18-28.

Manchineella, S., Thrivikraman, G., Basu, B. and Govindaraju, T., 2016. Surfacefunctionalized silk fibroin films as a platform to guide neuron-like differentiation of human mesenchymal stem cells. ACS applied materials \& interfaces, 8(35), pp.22849-22859.

Nakamura, Y., Yamanaka, H., Hata, Y., Ebato, A., and Koike, K. (2012). Development of the novel hair coloring system using enzymatically-prepared melanin precursors by Aspergillus oryzae tyrosinase. SeibutsuKogakuKaishi 90, 115-121.

Nicolaus, R.A., Piattelli, M. and Fattorusso, E., 1964. The structure of melanins and melanogenesis-IV: On some natural melanins. Tetrahedron, 20(5), pp.1163-1172

Pillaiyar, T., Manickam, M. and Jung, S.H., 2015. Inhibitors of melanogenesis: a patent review (2009-2014). Expert opinion on therapeutic patents, 25(7), pp.775-788.

Pogenberg, V., Ögmundsdóttir, M.H., Bergsteinsdóttir, K., Schepsky, A., Phung, B., Deineko, V., Milewski, M., Steingrímsson, E. and Wilmanns, M., 2012. Restricted leucine zipper dimerization and specificity of DNA recognition of the melanocyte master regulator MITF. Genes \& development, 26(23), pp.2647-2658.

Pralea, I.E., Moldovan, R.C., Petrache, A.M., Ilieș, M., Hegheș, S.C., Ielciu, I., Nicoară, R., Moldovan, M., Ene, M., Radu, M. and Uifălean, A., 2019. From Extraction to Advanced Analytical Methods: The Challenges of Melanin Analysis. International journal of molecular sciences, 20(16), p.3943.

Qi, C., Fu, L.H., Xu, H., Wang, T.F., Lin, J. and Huang, P., 2019. Melanin/polydopaminebased nanomaterials for biomedical applications. Science China Chemistry, 62(2), pp.162-188.

Raper, H.S., 1928. The aerobic oxidases. Physiological Reviews, 8(2), pp.245-282.

Schweitzer, A.D., Revskaya, E., Chu, P., Pazo, V., Friedman, M., Nosanchuk, J.D., Cahill, S., Frases, S., Casadevall, A. and Dadachova, E., 2010. Melanin-covered nanoparticles for protection of bone marrow during radiation 
therapy of cancer. International Journal of Radiation Oncology* Biology* Physics, 78(5), pp.1494-1502.

Sealy, R.C., 1984. Free radicals in melanin formation, structure and reactions. Free radicals in molecular biology, aging and disease, pp.67-76

Singh, D., Kumar, J. and Kumar, A., 2018. Isolation of pyomelanin from bacteria and evidences showing its synthesis by 4hydroxyphenylpyruvate dioxygenase enzyme encoded by hppD gene. International journal of biological macromolecules, 119, pp.864-873.

Slominski, A., Tobin, D.J., Shibahara, S. and Wortsman, J., 2004. Melanin pigmentation in mammalian skin and its hormonal regulation. Physiological reviews, 84(4), pp.1155-1228.

Solano, F., 2014. Melanins: skin pigments and much more-types, structural models, biological functions, and formation routes. New Journal of Science, 2014.ritz RA (2011) The genetics of vitiligo. J Invest Dermatol 131: E18-E20

Solano, F., 2017. Melanin and melanin-related polymers as materials with biomedical and biotechnological applications-cuttlefish ink and mussel foot proteins as inspired biomolecules. International journal of molecular sciences, 18(7), p.1561.

Spritz, R.A. and Hearing, V.J., 2013. Abnormalities of pigmentation. In Emery and Rimoin's principles and practice of medical genetics (pp. 1-44). Academic Press.

Sugumaran, M., 1998. Unified mechanism for sclerotization of insect cuticle. In Advances in Insect Physiology, 27, pp. 229-334

Sun, S.; Zhang, X.; Sun, S.; Zhang, L.; Shan, S.; Zhu, H. Production of natural melanin by Auriculariaauricula and study on its molecular structure. Food Chem. 2016, 190, 801-807

Vance, K.W. and Goding, C.R., 2004. The transcription network regulating melanocyte development and melanoma. Pigment cell research, 17(4), pp.318-325.

Videira, I.F.D.S., Moura, D.F.L. and Magina, S., 2013. Mechanisms regulating melanogenesis. Anaisbrasileiros de dermatologia, 88(1), pp.76-83.

Wang, C., Wang, D., Dai, T., Xu, P., Wu, P., Zou, Y., Yang, P., Hu, J., Li, Y. and Cheng, Y., 2018. Skin Pigmentation- Inspired Polydopamine Sunscreens. Advanced Functional Materials, 28(33), p.1802127.

Wang, L.F. and Rhim, J.W., 2019. Isolation and characterization of melanin from black garlic and sepia ink. $L W T, 99$, pp.17-23.

Wang, X.; Zhang, J.; Wang, Y.; Wang, C.; Xiao, J.; Zhang, Q.; Cheng, Y.Y. Multiresponsive photothermal-chemotherapy with drug-loaded melanin-like nanoparticles for synergetic tumor ablation. Biomaterials 2016, 81, 114-124.

Williams, R.F. Melanin-based Agents for Image Enhancement. U.S. Patent US 5,310,539, 10 May 1994.

Zhang, R.; Fan, Q.; Yang, M.; Cheng, K.; Lu, X.; Zhang, L.; Huang, W.; Cheng, Z. Drug delivery: Engineering melanin nanoparticles as an efficient drug-delivery system for imaging-guided chemotherapy (Adv. Mater.34/2015). Adv. Mater. 2015, 27, 5063-5069.

\section{How to cite this article:}

Triparna Pahari, Kasturi Chattopadhyay, Susmita Mukherjee and Susmita Jana. 2020. A Review on a Bio-Synthetic Pathway: Melanogenesis. Int.J.Curr.Microbiol.App.Sci. 9(05): 2372-2385. doi: https://doi.org/10.20546/ijcmas.2020.905.270 